\title{
NRXN2 Gene Product
}

National Cancer Institute

\section{Source}

National Cancer Institute. NRXN2 Gene Product. NCI Thesaurus. Code C124914.

A protein encoded by the NRXN2 gene. 